\title{
Pengaruh Pemberian Aromaterapi Ginger Oil (Zingiber officinale) Terhadap Emesis Gravidarum Pada Ibu Hamil Trimester I Di Klinik Makmur Jaya Tahun 2019
}

\author{
Bunga Tiara Carolin ${ }^{1 \text { ** }}$, Aisah Hairul Ummahi) \\ Email: bunga.tiara@civitas.unas.ac.id \\ ${ }^{1)}$ Program Studi DIV Kebidanan, Fakultas Kesehatan, Universitas Nasional Jakarta
}

\begin{abstract}
ABSTRAK
Pada trimester pertama kemungkinan besar wanita akan mengalami mual-mual dengan atau tanpa muntah. Gejala ini di mulai sekitar minggu ke enam kehamilan dan biasanya menurun drastis di akhir trimester pertama, salah satu cara mengatasi rasa mual pada ibu hamil adalah dengan pemberian ginger oil yang mempunyai kandungan minyak atsiri yang mempunyai efek menyegarkan, memblokir reflek muntah, melancarkan peredaran darah serta membuat syarafsyaraf bekerja dengan baik. Penelitian ini bertujuan untuk mengetahui pengaruh penggunaan ginger oil terhadap emesis gravidarum pada ibu hamil trimester I di Klinik Makmur Jaya Tahun 2019. Desain penelitian quasi-experiment ini menggunakan metode One Group Pretest-Postest Design. Sampel dalam penelitian ini berjumlah 30 ibu hamil trimester I yang mengalami mual. Teknik pengambilan sampel yang digunakan adalah total sampling. Instrumen penelitian berupa Skor PUQE yang digunakan untuk menilai derajat mual dan muntah pada wanita hamil. Data dianalisis menggunakan descriptive statistics yaitu paired $t$-test. Hasil penelitian menunjukkan bahwa ada perbedaan yang signifikan pada derajat mual ibu hamil sebelum dan sesudah diberikan aromaterapi ginger oil pada kelompok eksperimen $(\mathrm{p}<0,05)$. Simpulannya bahwa ginger oil dapat mengurangi derajat mual pada ibu hamil. Diharapkan program ini dapat diaplikasikan di praktik kebidanan khususnya pasien hamil trimester I dengan keluhan mual dan sebagai bahasan rujukan untuk penelitian selanjutnya.
\end{abstract}

Kata kunci: Ibu Hamil Trimester I, Emesis, Ginger Oil.

\begin{abstract}
In the first trimester, it is likely that women will experience nausea with or without vomiting. This symptom starts around the sixth week of pregnancy and usually drops dramatically at the end of the first trimester, one way to deal with nausea in pregnant women is by giving ginger oil which contains essential oils that have a refreshing effect, blocking vomiting reflexes, blood circulation and make the nerves work properly.This study aimed to determine the effect of using ginger oil on emesis gravidarum among first trimester pregnant women in the Makmur Jaya Clinic in 2019.This quasi-experimental study used the design of the One Group Pretest-Posttest Design. The sample in this study were 30 first trimester pregnant women who experienced nausea. The sampling technique used was total sampling. The research instrument was a PUQE score to assess the degree of nausea and vomiting among pregnant women. Data were analyzed using descriptive statistics, namely paired t-test. The results showed that there were a significant difference in the degree of nausea of pregnant women before and after intervention in the experimental group $(p<0.05)$. the Conclusions showed Ginger oil can reduce the degree of nausea among pregnant women. This program can be applied in midwifery practice, especially for pregnant women in the first trimester with complaints of nausea and as a references for future research.
\end{abstract}

Keywords: Pregnant Women Trimester I, Emesis, Ginger Oil. 


\section{A. LATAR BELAKANG}

Kehamilan adalah serangkaian proses yang diawali dari konsepsi atau pertemuan antara ovum dan sperma sehat yang dilanjutkan dengan fertilisasi, nidasi dan implantasi. [1] Sekitar $51,4 \%$ wanita mengalami mual dan $9,2 \%$ wanita mengalami muntah.[2]

Mual dan muntah selama kehamilan biasanya disebabkan oleh perubahan dalam sistem endoktrin yang terjadi selama kehamilan, terutama disebabkan oleh Human Chorionic Gonadotropin (HCG), khususnya karena periode mual dan muntah gestasional yang paling umum adalah pada usia 12-16 minggu pertama, pada saat itu HCG mencapai kadar tertinggi.[2]

Emesis gravidarum adalah muntah yang terjadi awal kehamilan sampai umur 20 minggu. Emesis Gravidarum dalam keadaan normal tidak banyak menimbulkan efek negative terhadap kehamilan dan janin, hanya saja apabila emesis gravidarum ini berkelanjutan berubah menjadi Hiperemesis Gravidarum yang meningkatkan resiko terjadinya gangguan pada kehamilan. Untuk mengatasinya dengan pemberian obatobat yang relatif ringan.[3]

Penatalaksanaan mual dan muntah pada kehamilan tergantung pada beratnya gejala. Pengobatan dapat dilakukan dengan cara farmakologi maupun non farmakologi. Terapi farmakologi dilakukan dengan pemberian antiemetik, antihistamin, anti-kolinergik dan kortikosteroid. Terapi nonfarmakologi dilakukan dengan cara pengaturan diet, dukungan emosional, akupuntur dan jahe. [4]

Jahe (ginger) adalah tanaman dengan sejuta khasiat yang telah dikenal sejak lama. Rimpangnya sangat banyak manfaatnya, antara lain sebagai bumbu masak, minuman, serta permen dan juga digunakan dalam ramuan obat tradisianal.[5] Keungulan pertama jahe adalah kandungan minyak atsiri yang mempunyai efek menyegarkan dan memblokir reflek muntah, sedang gingerol dapat melancarkan peredaran darah dan saraf-saraf bekerja dengan baik. Hasilnya ketegangan bisa dicairkan, kepala jadi segar, mual muntah pun ditekan. Aroma harum jahe dihasilkan oleh minyak arsiri, sedang oleoresisnya menyebabkan rasa pedas yang menghangatkan tubuh dan mengeluarkan keringat.[6]

Menurut sebuah ulasan yang dipublikasikan oleh jurnal obstetrik \& Ginekologi, jahe dapat membantu para wanita hamil mengatasi derita morning sickness tanpa menimbulkan efek samping yang membahayakan janin di dalam kandungannya.[4] Beberapa hasil penelitian menunjukkan bahwa jahe merupakan bahan terapi untuk meredakan dan mengurangi rasa mual dan muntah.[7],[8] Selain itu jahe juga efektif dalam mengurangi emesis gravidarum pada ibu hamil trimester pertama kehamilan dan menurunkan mual muntah pada ibu yang multigravida. [9]

Berdasarkan data yang diperoleh dari Klinik Makmur Jaya dari 50 ibu hamil trimester I ditemukan adanya $30 \mathrm{ibu}$ hamil trimester I yang mengalami mual pada kehamilan. Berdasarkan latar belakang di atas penulis tertarik untuk mengambil judul "Pengaruh Pemberian Aromaterapi Ginger Oil terhadap Emesis Gravidarum Pada Ibu Hamil Trimester I di Klinik Makmur Jaya Tahun 2019”.

\section{B. METODE PENELITIAN}

Penelitian ini menggunakan desain Quasi Experiment dengan metode One Group PretestPostest Design. Teknik pengambilan sampel yang digunakan adalah total sampling, dan data di analisis menggunakan Independent Samples T-Test. Penelitian ini dilakukan di Klinik Makmur Jaya, dengan sampel penelitian ibu hamil trimester I yang mengalami mual di Klinik Makmur Jaya sebanyak 30 ibu hamil. Hasil uji normalitas dengan melihat hasil test of normality Shapiro-Wilk, diperoleh hasil nilai $P$-Value lebih dari 0,05. dengan demikian, dapat diambil kesimpulan bahwa data berdistribusi normal.

\section{HASIL DAN PEMBAHASAN}

\section{Hasil}


Tabel 1 Karakteristik Responden berdasarkan Pendidikan di Klinik Makmur Jaya

\begin{tabular}{|c|c|c|}
\hline Pendidikan & Frekuensi & Persentase \\
\hline SMP & 2 & 6,7 \\
\hline SMA & 21 & 70 \\
\hline Perguruan Tinggi & 7 & 23,3 \\
\hline Jumlah & 30 & 100 \\
\hline
\end{tabular}

Berdasarkan tabel 1, karakteristik responden berdasarkan pendidikan paling tertinggi adalah SMA dengan jumlah 21 orang (70\%).

\section{Tabel 2 Karakteristik Responden berdasarkan Pekerjaan di Klinik Makmur Jaya}

\begin{tabular}{|c|c|c|}
\hline Pekerjaan & Frekuensi & Persentase \\
\hline Ibu Rumah Tangga & 16 & 53,3 \\
\hline Karyawan & 8 & 26,7 \\
\hline Wiraswasta & 2 & 6,7 \\
\hline Lain-lain & 4 & 23,3 \\
\hline Jumlah & 30 & 100 \\
\hline
\end{tabular}

Berdasarkan tabel 2, karakteristik responden berdasarkan pekerjaan, pekerjaan tertinggi pada responden ialah ibu rumah tangga yang berjumlah 16 orang $(53,3 \%)$.

\section{Tabel 3 Distribusi Responden yang mengalami mual sebelum diberikan ginger oil di Klinik Makmur Jaya}

\begin{tabular}{|c|c|c|}
\hline $\begin{array}{c}\text { Sebelum pemberian } \\
\text { ginger oil }\end{array}$ & Frekuensi & Persentase \\
\hline Ringan & 7 & 23,3 \\
\hline Sedang & 17 & 56,7 \\
\hline Berat & 6 & 20 \\
\hline Jumlah & 30 & 100 \\
\hline
\end{tabular}

Berdasarkan tabel 2, distribusi responden yang mengalami mual sebelum pemberian ginger oil dengan tingkatan tertinggi adalah responden yang mengalami mual sedang dengan jumlah responden 17 orang $(56,7 \%)$, lalu responden dengan mual ringan yang berjumlah 7 orang $(23,3 \%)$, responden yang mengalami mual berat berjumlah 6 orang (20\%).

\section{Tabel 4 Distribusi Responden yang mengalami mual sesudah diberikan ginger oil di Klinik Makmur Jaya}

\begin{tabular}{|c|c|c|}
\hline $\begin{array}{c}\text { Sesudah pemberian } \\
\text { ginger oil }\end{array}$ & Frekuensi & Prersentase \\
\hline Ringan & 19 & 63,3 \\
\hline Sedang & 8 & 26,7 \\
\hline Berat & 3 & 10,0 \\
\hline Jumlah & 30 & 100 \\
\hline
\end{tabular}

Berdasarkan tabel 4, distribusi responden yang mengalami mual sesudah pemberian ginger oil dengan tingkatan tertinggi adalah responden yang mengalami mual ringan dengan jumlah responden 19 orang $(63,3 \%)$, mual sedang berjumlah 8 orang $(26,7 \%)$, responden yang mengalami mual berat berjumlah 3 orang $(10,0 \%)$.

Tabel 5 Distribusi Pengaruh Pemberian ginger oil di Klinik Makmur Jaya

\begin{tabular}{|c|c|c|c|c|c|}
\hline Kelompok & Mean & SD & SE & $\begin{array}{c}\text { P- } \\
\text { Value }\end{array}$ & N \\
\hline Pre test & 1,97 & 0,669 & 0,122 & 0,001 & 30 \\
\hline Post test & 1,67 & 0,711 & 0,130 & & 30 \\
\hline
\end{tabular}

Berdasakan tabel 5 diatas maka didapatkan hasil dengan mean sebelum diberikan perlakuan 1,97 dengan standard deviasi 0,669 dan sesudah diberikan perlakuan di dapatkan hasil mean 1,67 dengan standard deviasi 0,711. Terlihat penurunan derajat mual antara pre dan post yaitu 0.300 selain itu didapatkan juga nilai $\mathrm{P}=0,001<$ 0,05 maka didapatkan adanya pengaruh antara sebelum perlakuan dan setelah perlakuan.

\section{Pembahasan}

Berdasarkan penelitian di Klinik Makmur Jaya didapatkan hasil skala mual dengan tingkatan tertinggi adalah responden yang mengalami mual sedang dengan presentasi mencapai $56,7 \%$, lalu responden dengan mual ringan dengan presentasi $23,3 \%$, responden yang mengalami mual berat dengan presentasi $20 \%$.

Kandungan di dalam jahe terdapat minyak Atsiri Zingiberena (zingirona), zingiberol, bisabilena, kurkumen, gingerol, flandrena, vit A dan resin pahit yang dapat memblok serotinin yaitu suatu neurotransmitter yang di sintesiskan pada neuron neuronserotonergis dalam sistem saraf pusat dan sel-sel enterokromafin dalam saluran pencernaan sehingga di percaya dapat sebagai pemberiperasaan nyaman dalam perut sehingga dipercaya sebagai pemberi perasaan nyaman dalam perut sehingga dapat mengatasi mual muntah. [10]

Hasil penelitian ini di dukung oleh teori Prawirohardjo (2010) [3] yang mengatakan 
bahwa emesis gravidarum adalah muntah yang terjadi awal kehamilan sampai umur 20 minggu. Emesis Gravidarum dalam keadaan normal tidak banyak menimbulkan efek negative terhadap kehamilan dan janin, hanya saja apabila emesis gravidarum ini berkelanjutan berubah menjadi Hiperemesis Gravidarum yang meningkatkan resiko terjadinya gangguan pada kehamilan. Untuk mengatasinya dengan pemberian obatobat yang relatif ringan.

Penelitian ini juga didukung oleh teori yang diungkapkan oleh Runiari (2010) [4] bahwa Mual dan muntah pada kehamilan biasanya bersifat ringan dan merupakan kondisi yang dapat dikontrol sesuai dengan kondisi ibu hamil. Kondisi tersebut terkadang berhenti pada trimester pertama, namun pengaruhnya menimbulkan gangguan nutrisi, dehidrasi, kelemahan, penurunan berat badan, serta ketidakseimbangan elektrolit. Mual dan muntah pada kehamilan berlebih tidak hanya mengancam kehidupan ibu hamil, namun juga dapat menyebabkan efek samping pada janin seperti abortus, bayi lahir rendah, kelahiran prematur, serta malforasi pada bayi baru lahir. Kejadian pertumbuhan janin terhambat (Intrauterine growth retardation/ IUGR) meningkat pada wanita hamil dengan hiperemesis gravidarum.

Hasil penelitian ini didukung oleh teori Hernani (2013) [6] Jahe adalah tanaman dengan sejuta khasiat yang telah dikenal sejak lama. Rimpangnya sangat banyak manfaatnya, antara lain sebagai bumbu masak, minuman, serta permen dan juga digunakan dalam ramuan obat tradisianal. Keungulan pertama jahe adalah kandungan minyak atsiri yang mempunyai efek menyegarkan dan memblokir reflek muntah, sedang gingerol dapat melancarkan darah dan saraf-saraf bekerja dengan baik. Hasilnya ketegangan bisa dicairkan, kepala jadi segar, mual muntah pun ditekan. Aroma harum jahe dihasilkan oleh minyak arsiri, sedang oleoresisnya menyebabkan rasa pedas yang menghangatkan tubuh dan mengeluarkan keringat.
Terapi farmakologi dilakukan dengan pemberian antiemetik, antihistamin, antikolinergik, dan kortikosteroid. Mual dan muntah pada ibu hamil trimester pertama di masyarakat masih terjadi dan cara penanggulangannya sebagian besar masih menggunakan terapi farmakologis. Akan lebih baik jika ibu hamil mampu mengatasi masalah mual pada awal kehamilan dengan menggunakan terapi pelengkap nonfarmakologis terlebih dahulu. Karena terapi pelengkap nonfarmakologis bersifat non-instruktif, noninfasif, murah, sederhana, efektif dan tanpa efek samping yang merugikan.

Hasil penelitian ini juga sejalan dengan penelitian yang memaparkan bahwa pemberian terapi minuman jahe menunjukan penurunan morning sickness pada ibu hamil trimester I, sesudah diberikan terapi minuman jahe. [11] Begitu juga dengan hasil penelitian lain bahwa Aromaterapi jahe dapat menurunkan frekuensi mual dan mual muntah akibat kemoterapi pada penderita kanker payudara. [12]

Menurut asumsi penulis Terapi nonfarmakologi dapat dilakukan dengan cara pengaturan diet, dukungan emosional, akupuntur dan jahe. Aromaterapi jahe memberikan ragam efek bagi penghirupnya karena mempunyai efek menyegarkan, memblokir reflek muntah, melancarkan peredaran darah serta membuat syaraf-syaraf bekerja dengan baik.

\section{KESIMPULAN}

Simpulan dari penelitian ini yaitu ada pengaruh pemberian aromaterapi ginger oil terhadap emesis gravidarum pada ibu hamil trimester I di Klinik Makmur Jaya Tahun 2019.

\section{DAFTAR PUSTAKA}

[1] Sulistyawati, A. 2012. Asuhan Kebidanan pada Masa Kehamilan. Jakarta: Salemba Medika

[2] Tiran. 2008. Seri Asuhan Kebidanan Mual dan Muntah Dalam Kehamilan. Jakarta: EGC 
[3] Prawirohardjo, S. 2014. Ilmu Kebidanan. Edisi Ke Empat Cetakan Ke Empat. Jakarta: Yayasan Bina Pustaka Sarwono Prawirohardjo

[4] Runiari, N. 2010. Asuhan Keperawatan pada Klien dengan Hiperemesis Gravidarum: Penerapan Konsep dan Teori Keperawatan. Jakarta: Salemba Medika.

[5] Ramadhan, A. 2013. Aneka Manfaat Ampuh Rimpang Jahe untuk Pengobatan. Yogyakarta: Diandra Pustaka Indonesia.

[6] Hernani dan Winarti, C. 2013. Kandungan Bahan Aktif Jahe dan Pemanfaatannya dalam Bidang Kesehatan. Bogor: Balai Besar Penelitian dan Pengembangan Pascapanen Pertanian.

[7] Wiraharja, R,. S, dkk. 2011. Kegunaan Jahe Untuk Mengatasi Gejala Mual dalam Kehamilan. Jakarta: Jurnal of Medicine, Vol. 1, pp. 161- 170.

[8] Quinland, RH and Hill, DA. 2003. Nausea and vomiting of pregnancy. 121, s.l.: Am Fam Physicians, Vol. 68.

[9] Saswita. 2013. Efektifitas Jahe Dalam Mengurangi Emesis Gravidarum pada Ibu Hamil Trimester I. Jurnal Ners Indonesia, Vol. 2.

[10] Ahmad, J. 2013. Aneka Manfaat ampuh rimpang jahe untuk pengobatan. Yogyakarta: Dandra Pustaka Indonesia.

[11] Ardani, A. 2013. Perbandingan Efektifitas Pemberian Terapi Minuman Jahe dengan Minuman Kapulaga Terhadap Morning Sickness pada Ibu Hamil Trimester I di Keluarahan Ngempon Kecamatan Bergas Kabupaten Semarang. Semarang: STIKES Ngudi Waluyo Ungaran.

[12] Enikmawati, A .2016. Pengaruh Aromaterapi Jahe Terhadap Mual Dan Muntah Akibat Kemoterapi Pada Penderita Kanker Payudara Di Rs Pku Muhammadiyah Surakarta. Thesis. Yogyakarta 